\title{
Comparison of Urine Volume, Glomerular Filtration Rate, Excretion and Fraction of Reabsorption of Major Substances in Urine in Three Different Rat Strains
}

\author{
Naomi KOBAYASHI, Isao IKARASHI, Yoshiko FURUYAMA, \\ Kyoko BARADA, and Kiyonori TAUCHI \\ Imamichi Institute for Animal Reproduction, 1,103 Fukaya, Dejima-mura, \\ Niihari-gun, Ibaraki 300-01, Japan
}

(Received 16 July 1993/Accepted 10 November 1993)

\begin{abstract}
Urine volume(UV), Glomerular filtration rate (GFR) and Fraction of reabsorption (FR) of water, $\mathrm{Ca}, \mathrm{IP}, \mathrm{Na}^{+}, \mathrm{K}^{+}, \mathrm{Cl}^{-}, \mathrm{Glu}$ and $\mathrm{UN}$, which are significant in kidney function analysis, were investigated and compared in three rat strains (WI, SD and F344). UV/ body weight ratios were higher in $\mathrm{SD}$ rats as compared to other strains. The GFR difference was not significant, but the $\mathrm{FRH}_{2} \mathrm{O}$ difference was significant in three rat strains. $\mathrm{FR}$ of $\mathrm{Ca}, \mathrm{K}^{+}$and Glu showed no significant differences in three different rat strains. SD and F344 were significantly lower than WI in FR of IP. FR of $\mathrm{Na}^{+}, \mathrm{Cl}^{-}$and UN were significantly different in three rat strains without $\mathrm{Cl}^{-}$between $\mathrm{SD}$ and $\mathrm{F} 344$, and UN between WI and SD.-KEY WORDS : FR, GFR, rat strain, UV
\end{abstract}

\section{3 系統のラットにおける尿量, 糸球体濾過量, 主要成分の 尿中排泄量および再吸収分画の比較}

小林直美 - 五十嵐 功 ·古山佳子

茨田享子・田内清憲

財団法人動物繁殖研究所

尿検査は採血を伴う臨床検查と比較して動物に及ほ すストレスが小さく，また，採取された尿を分析する ことにより多くの情報を得ることが出来る $[9]$ 。事実, 尿は, 身体の物質代謝の終末産物である多くの物質を 溶存し, 濃縮されるので, 体内に起こったわずかな変 化が拡大, 強調されて現れることが多いため, 尿検査 は生体への薬物の影響を調べる一つの手段として有意 義であるといわれている 88$]$ 。

また，尿生成過程においては，腎系球体および尿細 管を通過するあいだに種々の物質の再吸収，尿の濃 縮・希釈, 分泌などが行われ, 最終的に尿が生成され
る。したがって，尿性状の変化ないし異常は，腎の障 害ないし腎機能異常を知る上で重要な指標となる $[15]$ 。

しかしながら，尿中物質と対応する血液生化学的検 査を行い, 系球体濾過量 (Glomerular filtration rate : GFR) および各種物質の再吸収分画 (fraction of reabsorption：FR）を算出，考察している文献はほとんど ない。そこで，䏝性試験に多用されている，WistarImamichi (WI) 系, Sprague-Dawley (SD) 系扰よ び Fisher 344 (F344) 系ラットを用いて, 腎機能検査 で重要とされる尿量, GFR, および水分, $\mathrm{Ca}, \mathrm{IP}, \mathrm{Na}^{+}$, $\mathrm{K}^{+}, \mathrm{Cl}^{-}$, Glu ならびに UN の排泄量および FR $[4,6$, 
15をを測定した。

\section{材料および方法}

1. 供試動物：8 週柃の Wistar-Imamichi (WI) 系 (財団法人動物繁殖研究所), Fisher 344 (F344)

系および Sprague-Dawley (SD) 系（日本チャー ルスリバー株式会社) SPFラットの雄各 5 匹を供 試した。

2. 動物の飼育：室温 $24 \pm 2{ }^{\circ} \mathrm{C}$, 相対湿度 $55 \pm 10 \%$, 換気回数 $10 \sim 20$ 回 $/ \mathrm{hr}$, 照明時間 14 時間 $(5 \sim 19$ 時) の動物室内で飼育し, 飼料 $(\mathrm{CRF}-1$; Oriental Yeast Ltd.）および飲料水（自家水道水）を自由 摂取させた。

3，尿検査：ラット用代謝ケージ（Metabolic cage； Shinano Co. Ltd.)を用いて24時間尿 $(9: 00 \mathrm{am}$ 9：00am)を採取し，尿量の測定を行った。採取し た尿は，生化学自動分析装置（Model RS1100； Jeol Ltd.) でクレアチニン (Creat ; 酵素法), カ ルシウム (Ca；OCPC 法), 無機リン (IP；酵素 法)，グルコース (Glu；酵素法）および尿素窒素 ( UN ; 酵素法) 濃度を, 電解質自動分析装置 (Model EL-ISE ; Beckman Instruments Inc.) でナトリウム $\left(\mathrm{Na}^{+}\right.$; イオン選択電極法), カリウ ム $\left(\mathrm{K}^{+}\right.$; イオン選択電極法 $)$おび塩素 $\left(\mathrm{Cl}^{-}\right.$; イオン選択電極法）濃度を測定した。

4. 血液化学的検查: 尿検査終了後に, エーテル麻酔 下で，腹大動脈から $18 \mathrm{G}$ の翼付き静注針を用いて 採血し, 無処置 (plain) の試験管 (Venoject, Autosep ; Terumo Inc.) に採取した。3,000rpm, 10 分間, $4{ }^{\circ} \mathrm{C}$ で遠心分離を行い, 血清を分離し, 血清の Creat, $\mathrm{Ca}, \mathrm{IP}, \mathrm{Na}^{+}, \mathrm{K}^{+}, \mathrm{Cl}^{-}$, Glu およ びUN 濃度を尿と同様の方法で測定した。

なお，供試ラットは，採血前16時間の絶食を行つ た。

5.GFR および FRの算出: 尿中 Creat 濃度, 血清 Creat 濃度および尿量から, 次式 1 )により, GFR を, GFR および尿量から, 次式 2 )により水の FR $\left(\mathrm{FRH}_{2} \mathrm{O}\right)$ を求めた。Ca, IP, $\mathrm{Na}^{+}, \mathrm{K}^{+}, \mathrm{Cl}^{-}$, Glu および UN の FR も血清濃度, GFR, 尿中濃 度および尿量から次式 3 ）により求めた。

1) $\mathrm{GFR}(\mathrm{m} \ell / \mathrm{min})$ $=($ 尿中Creat濃度 $\div$ 血清Creat濃度 $) \times 1$ 分間の尿量
$=($ 尿中 Creat 濃度 $\div$ 血清 Creat 濃度 $)$

$$
\times \text { 尿量 }(\mathrm{ml}) \div 24 \text { 時間 } \div 60 \text { 分 }
$$

2) $\mathrm{FRH}_{2} \mathrm{O}(\%)$

$$
\begin{aligned}
& =(\mathrm{GFR}-1 \text { 分間の尿量 }) \div \mathrm{GFR} \times 100 \\
& =[(\mathrm{GFR}-(\text { 尿量 } \div 24 \div 60)] \div \mathrm{GFR} \times 100
\end{aligned}
$$

3) $\mathrm{FR} * *(\%)$

$$
\begin{aligned}
& =(\text { 血清 } * * \text { 濃度 } \times \mathrm{GFR}) \\
& -(1 \text { 分間の尿中 } * * \text { 排泄量 }) \\
& \quad \div(\text { 血清 } * * \text { 濃度 } \times \mathrm{GFR}) \times 100 \\
& =[(\text { 血清 } * * \text { 濃度 } \times \text { GFR }) \\
& \quad-(\text { 尿中 } * * \text { 濃度 } \times \text { 尿量 } \div 24 \div 60)] \\
& \quad \div(\text { 血清 } * * \text { 濃度 } \times \mathrm{GFR}) \times 100
\end{aligned}
$$

$* *$ : Ca, IP, $\mathrm{Na}^{+}, \mathrm{K}^{+}, \mathrm{Cl}^{-}, \mathrm{Glu}, \mathrm{UN}$

6. 統計学的解析：尿量, GFR および各 FR ごとに, WI 系ラットとその他の系のラット群間で, 平均 値の差の検定 $(\mathrm{P}<0.05$ または $\mathrm{P}<0.001)$ を行っ た $[14]$ 。

\section{成}

Table 1 に, 供試したラットの体重, 尿量および尿 量/体重 $(\mathrm{ml} / 100 \mathrm{~g})$ 比を各系統ごとに平均值で示し た。 SD 系ラットの尿量は, WI 系ラットに比較して有 意に多かったが, F344系と WI 系ラットとの間に有意 差を認めなかった。また，尿量/体重比は, WI 系3.74, $\mathrm{SD}$ 系5.75および F 344 系3.48であり, $\mathrm{SD}$ 系が他の系 統と比較して統計学的に有意に高い値を示した。

Fig. 1 に，各系統のラットの GFR および $\mathrm{FRH}_{2} \mathrm{O}$ を示した。GFR は各系統間で統計学的有意差を認めな かった。 $\mathrm{FRH}_{2} \mathrm{O}$ は, $\mathrm{SD}$ 系ラットはWI 系および $\mathrm{F} 344$ 系に比較して小さい值を, F344系ラットはWI 系と比 較して大きい值を示した。

Fig. 2 に, 各系統の Ca および IP の尿中排泄量およ びFR を示した。Caの尿中排泄量は, 系統間で有意差 を認めなかった。IPの尿中排泄量は, SD 系および F344系ラットは, WI 系ラットと比較して有意に多か った。Caの FR は, 各系統間で有意差を認めなかった が, IPの FRは，SD 系およびF344系ラット共に WI 系ラットと比較して有意に低い值を示した。

Fig. 3 に, 各系統の $\mathrm{Na}^{+}, \mathrm{K}^{+} お よ ひ ゙ ~ \mathrm{Cl}^{-}$の尿中排泄

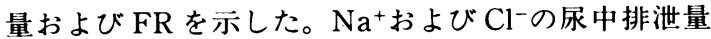
は, SD 系および F344系ラット共に WI 系ラットと比 
Table 1. Body weight (B. W.), urine volume (U. V.) and urine volume/body weight ratios in three different rat strains

\begin{tabular}{lcccc}
\hline & $\begin{array}{c}\text { Wistar-Imamichi } \\
\text { (WI) }\end{array}$ & $\begin{array}{c}\text { Sprague-Dawley } \\
\text { (SD) }\end{array}$ & \multicolumn{2}{c}{$\begin{array}{c}\text { Fisher 344 } \\
\text { (F344) }\end{array}$} \\
\hline B. W. (g) & $294 \pm 4$ & $331 \pm 16^{* *}$ & $219 \pm 66^{* *} \$ \$$ \\
U. V. (m $/ 24 \mathrm{hr})$ & $11.0 \pm 2.2$ & $19.0 \pm 4.6^{* *}$ & $7.6 \pm 3.0$ & $\$ \$$ \\
U. V. B. W. & 3.74 & $5.75^{* *}$ & 3.48 & $\$ \$$ \\
\hline
\end{tabular}

** : Significantly different from W. I. value at $\mathrm{P}<0.01$

different from S. D. value at $\mathrm{P}<0.01$ (F344 only)

$\$ \$:$ Significantly
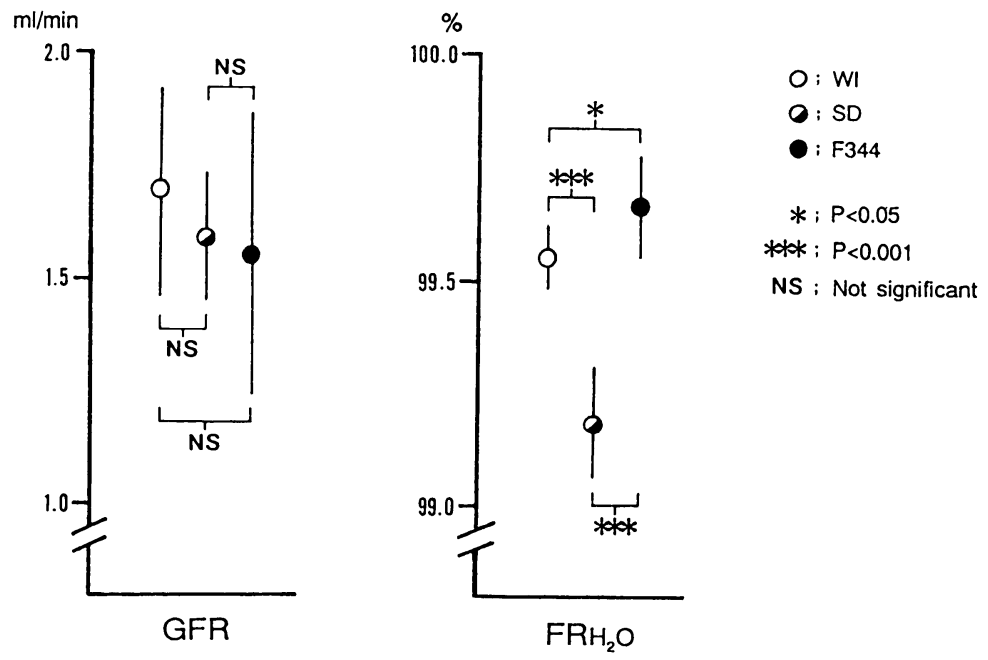

Fig. 1. Comparison of glomerular filtration rate(GFR) and fraction of reabsorption (FR) of water in three different rat strains
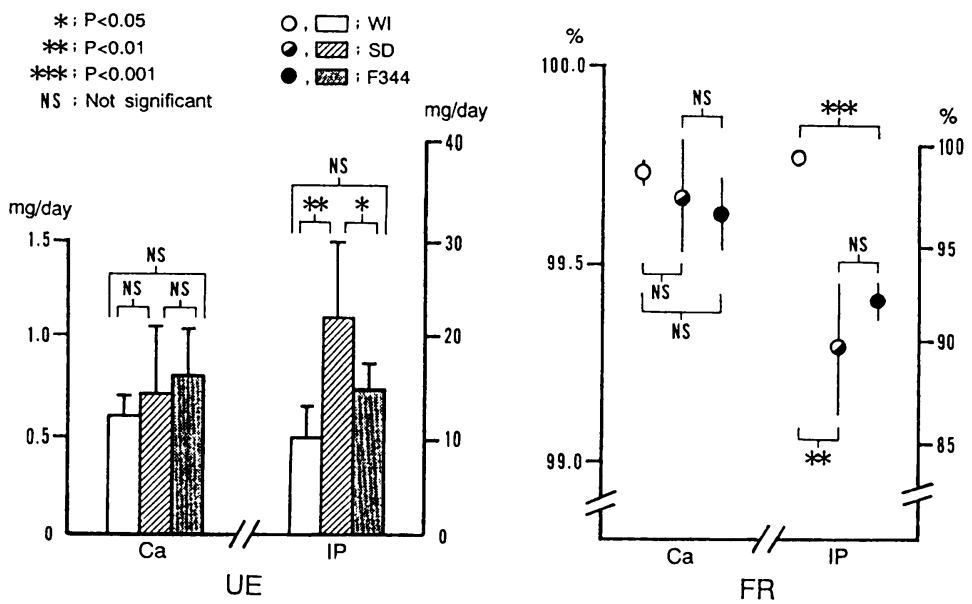

Fig. 2. Comparison of urine excretion (UE) and FR of calcium and inorganic phosphorous in three different rat strains 

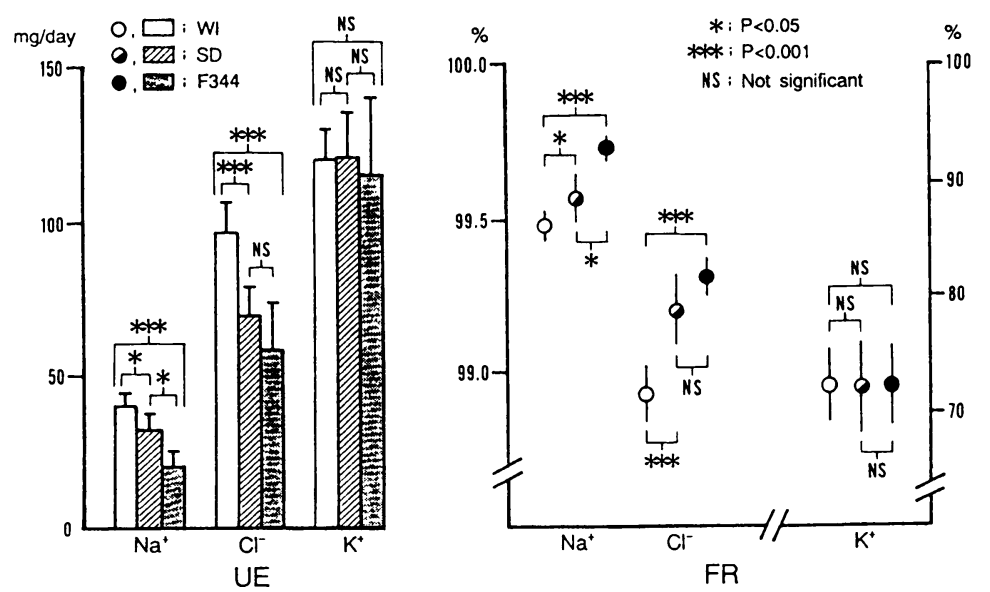

Fig. 3. Comparison of urine excretion (UE) and FR of electrolytes in three different rat strains
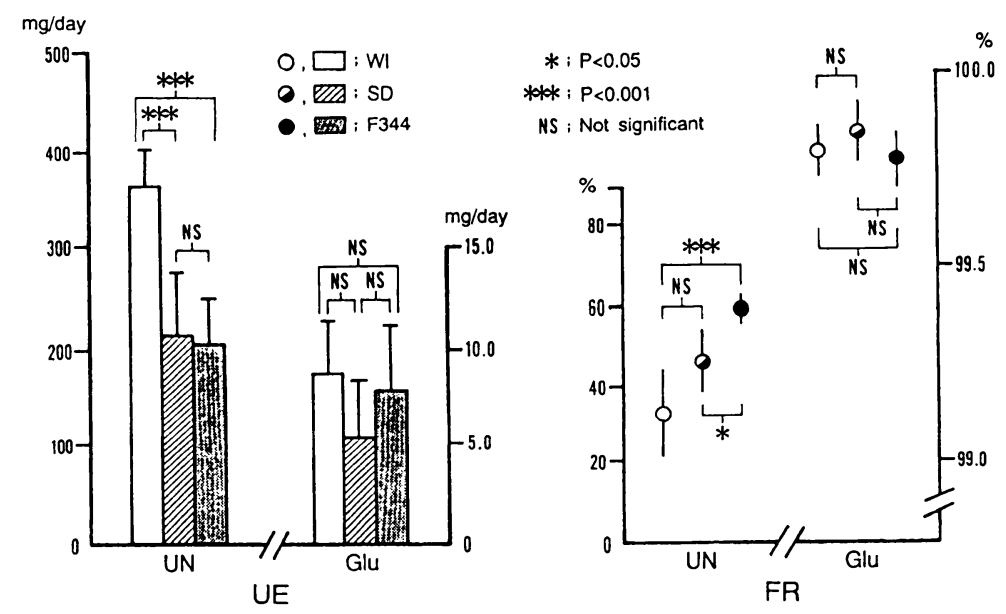

Fig. 4. Comparison of urine excretion (UE) and FR of urea nitrogen and glucose in three different rat strains

較して有意に少ない值を示した。 $\mathrm{K}^{+}$の尿中排泄量は各 系統間で有意差を認めなかった。 $\mathrm{Na}^{+}$および $\mathrm{Cl}^{-}$の $\mathrm{FR}$ は, $\mathrm{SD}$ 系㧍よび F344系ラット共に WI 系ラットと比 較して有意に大きかったが, $\mathrm{K}^{+}$の FR は各系統間で有 意差を認めなかった。

Fig. 4 に, 各系統のUN および Glu の尿中排泄量お よび FR を示した。UN の尿中排泄量は, SD 系および F344系ラット共にWI 系ラットと比較して小さい值 を示した。Glu の尿中排泄量は, 系統間で有意差を認め なかった。UNの FR は, SD 系ラットではWI 系ラッ
トとの間に有意差を認めなかったが, F344系ラットで は有意差を認めた。Gluの FR は, 各系統間で有意差を 認めなかった。

\section{考察}

堅毒性を有する薬物は数多く, 臨床においてしばし ば重篤な副作用を呈することが知られている。この場 合，尿性状の变化ないし異常は，留の障害ないし㫮機 能異常を知る上で重要な指標となりうる $[15]$ 。したが 
って, 腎毒性の検出を目的とする毒性試験をはじめ, 前臨床研究においては, 尿性状に関する検討が必要で ある [9]。

また，腎炎の初期には尿量および GFR の増加が, 腎 炎の末期には尿量および GFR の減少が起きることが 知られている $[3,5]$ 。したがって，腎機能を知るうえ で, 尿量の測定および GFRの算出は重要である。

しかしながら, 今回我々が行った GFR および FR の系統間における差については報告がなく，わずかに $\mathrm{pH}$, 糖および夕ンパクについて行つた尿定性試験が報 告されている $[10]$ に過ぎない。

さらに, 今回測定した $\mathrm{Na}^{+}, \mathrm{K}^{+}, \mathrm{Cl}^{-}, \mathrm{UN}$ および Gluの FR も尿細管機能を知るうえで非常に有益であ る。実際我々は, ゲンタマイシンによる実験的腎尿細 管障害で上記測定項目が変動することを経験してい る。

今回用いた 3 系統のラットの尿量は, 系統間で大き な差を認めた。特に, SD 系の24時間尿量および尿量/ 体重比はともに他の系統と比較して有意に大きい值を 示した。この理由は, GFRには差が認められないが, $\mathrm{FRH}_{2} \mathrm{O}$ が明らかに低值を示すことから, SD 系は，他 の系統と比較して腎における水の再吸収が少ないこと により尿量が増加したものと考えられた。

WI 系は, 尿中 IP 排泄量が他の系統に比較して少な いことから FR が他の系統に比較して有意に大きく，

$\mathrm{Na}^{+}, \mathrm{Cl}^{-}$およひ UN は, WI 系が他の系統に比較して 尿中排泄量が高い值を示していたことから FRは低い 值を示した。上記の差異は, 各種腎機能のうち, 特に 尿細管での $\mathrm{Na}^{+}, \mathrm{Cl}^{-} お$ よび UN の再吸収能が系統間 でかなり異なることを示唆している。

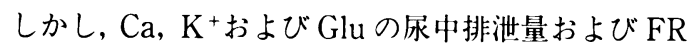
は，いずれの系統間でも有意差を恋めなかった。ここ で, $\mathrm{K}+の \mathrm{FR}$ は, 各系統とも約70\%程度と他の電解質 と比較して低い值を示したが, $\mathrm{K}^{+}$は尿細管で再分泌さ れること $[2,13,16]$ がその理由と考えられた。

また, 今回は, 毒性試験で一般的に行われている採 血時の絶食を行ったが, 絶食を行うことによって, 各 測定項目の血中濃度が採尿時と異なっている可能性が 考えられた。したがって, 今後は絶食を行わない条件 下での採血検査ならびに, 絶食条件下での採尿および 採血を行い，今回の実験との比較を行う必要があるも のと考えられる。

以上のように24時間尿量, 尿量/体重比, $\mathrm{FRH}_{2} \mathrm{O}$, IP, $\mathrm{Na}^{+}, \mathrm{Cl}^{-}$および UN の尿中排泄量および $\mathrm{FR}$ は,
各系統間で差がみられた。これ系統間差については, GFR および FR の検討により, 尿細管での水分ならび に IP, $\mathrm{Na}^{+}, \mathrm{Cl}^{-}$および UN の尿細管における再吸収能 の差が主たる原因と考えられた。したがって, 堅毒性 の評価に際しては, 用いる系統の差を考虑にいれる必 要があると考えられる。

また，今回用いたクレアチニンクリアランスによる GFRの算出法は, 従来用いられていた Jáffe [1] の試 薬に代えて, より特異性の高い酵素法 [12] を用いて いる。したがって, 従来から指摘されていたクレアチ ニン以外に Jáffe 試薬に反応する尿中 Chromogen の 影響 $[7,11]$ ならびに血清中の Glu およびケトン体の 影響を排除することにより，より一層精度の高い GFR を算出することが可能であったと考えられた。

\section{要 約}

WI 系, SD 系およびF344系ラットを用いて, 呰機能 検査で重要とされる尿量, GFR, および水分, $\mathrm{Ca}, \mathrm{IP}$, $\mathrm{Na}^{+}, \mathrm{K}^{+}, \mathrm{Cl}^{-}, \mathrm{Glu}$ および $\mathrm{UN}$ の排泄量および $\mathrm{FR}$ を 測定し, 比較検討した。SDラットは, 他の系統のラッ 卜と比較して, 尿量が多く, 尿量/体重比も大きかった。 GFR は，各系統間で差を認めなかったが, $\mathrm{FRH}_{2} \mathrm{O}$ は

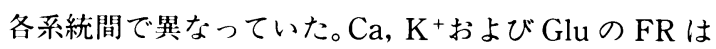
系統間で差を認めなかった。IPの FR は, SD 系および F344系ラット共にWI 系ラットと比較して有意に低 い值を示した。 $\mathrm{Na}^{+}, \mathrm{Cl}^{-}$おび UN の FR はほぼ同じ 傾向を示し, WI 系, SD 系および F344系の順に小さい 值をとり，SD と $\mathrm{F} 344$ 間の $\mathrm{Cl}^{-}$および WI と $\mathrm{SD}$ 間の UN を除き共に有意差を認めた。

\section{文献}

[1] Fabiny, D. L. and Ertingshausen, G. (1971). Automated reaction-rate method for determination of serum creatinine with the centrifichem. Clin. Chem., 17, 670-698.

[2] Furuya, H. and Asano, Y. (1992). Potassium metabolyte regulation. Modern Medical Laboratory, 20, $16-17$.

[ 3 ] Honda, K. and Saito, J. (1988). Analysis method of abnormal urine volume. Kidney and Dialysis, 24, 528 -532 .

[4] Horio, M. and Orita, Y. (1990). Sodium. J. Medical Technology, 34, 1280-1287.

[5] Ishida, N., Suzuki, T., and Yoshimura, S. (1992). Urine Volume. Modern Medical Laboratory, 20, 24-25.

[6] Ishimoto, F. and Misawa, T. (1990). Urine chemistry $-\mathrm{U}-\mathrm{N}$, creatinine, electrolytes, NAG, $\beta_{2}-\mathrm{m}$, citric acid-. Kidney and Dialysis, 29, 27-29. 
[7] Kawai, T. (1985). Creatinine - creatine. In Laboratory Medicine, pp 82-84, Igakusyoin. Tokyo.

[ 8 ] Kosaka, T. and Ebino, K. (1985). Ophthalomological analysis, urinalysis, electrocardiographic analysis. In New Toxicological study-Method and evaluation-, pp 99-105, Realize, Tokyo.

[9] Ono, H. (1990). Kidney function and urinalysis. In Functional toxicology. pp 486-495, Chijinsyokan, Tokyo.

［10］尾上正治・平野郁子・坂本経敏・小島賢二・高橋德太郎. (1981). F344/Yit ラットに関する研究, 一般毒性試験の検 査値における他の系統との比較.医学と蒋学，6，581-593.

[11] Sakai, O. and Ogura, M. (1989). Urine creatinine and creatine. Medicina, 26, 1646-1647.

[12] Suzuki, M. and Yoshida, M. (1976) . Enzymatic deter- mination of creatinine and creatine in serum. Clinical Symposium, 16, 220.

[13] Tabei, K. (1986). K regulation system. Kidney and Dialysis, 21, 167-173.

[14] Takizawa, T. (1985). Comparison of samples. In Veterinary statistics. pp 153-170, Gakusyosya, Tokyo.

[15] Tanimoto, Y. (1988). Quality of animal urine and significance of the examinations. In Biochemistry of blood and urine in experimental animals. pp 119-134, Soft Science, Tokyo.

[16] Wright, F. S. and Giehisch, G. (1992). Regulation of potassium excretion. In The Kidney (Second edition). pp 2,209-2,248, Raven Press, New York. 